Volume 1 Nomor 1, Februari 2016, halaman 14-22

\title{
DESAIN DIDAKTIS KONSEP LUAS PERMUKAAN DAN VOLUME PRISMA DALAM PEMBELAJARAN MATEMATIKA SMP
}

\author{
Lusi Siti Aisah $^{\mathbf{1}}$, Kusnandi ${ }^{2}$, Kartika Yulianti ${ }^{\mathbf{3}}$ \\ ${ }^{1}$ Universitas Wiralodra, lusi_sitiaisah@yahoo.com \\ ${ }^{2}$ Universitas Pendidikan Indonesia, kusnandiabadi@yahoo.co.id \\ ${ }^{3}$ Universitas Pendidikan Indonesia, ykar_tika@yahoo.com
}

\begin{abstract}
ABSTRAK
Penelitian ini bertujuan untuk menyusun suatu desain didaktis konsep luas permukaan dan volume prisma berdasarkan learning obstacle (kesulitan belajar) yang dialami siswa saat mempelajari konsep tersebut. Metode penelitian yang digunakan adalah metode kualitatif dengan teknik pengumpulan data yaitu observasi, tanyajawab, dan dokumentasi. Langkah awal dalam penelitian ini adalah mengidentifikasi learning obstacle dengan mengujikan instrumen learning obstacle kepada siswa kelas IX SMP dan X SMA yang telah mendapatkan/mempelajari materi tersebut. Setelah learning obstacle teridentifikasi, desain didaktis kemudian disusun dengan menyesuaikan pada teori-teori belajar yang relevan serta tidak mengurangi kemampuankemampuan matematika yang dapat dikembangkan. Desain didaktis yang telah disusun selanjutnya diimplementasikan pada proses pembelajaran kepada siswa kelas VIII SMP. Efektivitas desain didaktis diukur menggunakan derajat peningkatan yang dimodifikasi dari gain ternormalisasi Hake. Desain didaktis yang disusun telah menunjukkan efektivitas yang cukup, dengan kategori efektif sedang. Hasil implementasi dan efektivitas desain didaktis menunjukan bahwa desain didaktis yang telah disusun ini dapat dijadikan sebagai salah satu desain alternatif dalam mempelajari konsep luas permukaan dan volume prisma.
\end{abstract}

Kata kunci: Learning obstacle, Desain didaktis, Prisma.

\section{ABSTRACT}

The purpose of this study is to composing didactic design concept about surface area and volume of prismsbased on learning obstacle (learning difficulties) students when studying the concept.The research methods is qualitative methods with data collection techniques are observation, question and answer, and documentation. The initial step in this research is identifying learning obstacle with learning obstacle instrument to students in grade IX junior high school and grade $\mathrm{X}$ senior hign scool who has studied about that concept. After learning obstacle is identified, the didactic design then composed by adjusting the learning theories that are relevant and does not reduce mathematical abilities that can be developed. Didactic design which has been arrangedthen implemented in the students learning process on grade VIII SMP. Didactic design effectiveness was measured using a modified degree increase of the gain normalized Hake. Didactic design has show considerable effectiveness, with an effective medium category. Results of the implementation and effectiveness of the didactic design shows that the didactic design that has been composed can be used as one of the alternative designs in studying the concept of surface area and volume of prisms.

Keywords: Learning obstacle, Didactic design, Prism. 


\section{How to Cite: Aisah, L. S., Kusnandi, \& Kartika, Y. (2016). Desain Didaktis Konsep Luas Permukaan dan Volume Prisma dalam Pembelajaran Matematika SMP. Mathline: Jurnal Matematika dan Pendidikan Matematika, Vol.1, No.1, 14-22.}

\section{PENDAHULUAN}

Geometri merupakan sebuah subjek abstrak yang mudah untuk digambarkan dan mempunyai banyak penerapan praktis yang nyata (Ed, 2003). Tetapi, walaupun geometri mudah untuk digambarkan pada kenyataannya banyak siswa masih merasa kesulitan untuk memahami konsep geometri. Berdasarkan pengalaman guru-guru matematika, salah satu pokok bahasan yang sulit dipahami oleh siswa adalah pokok bahasan bangun ruang. Tidak hanya bagi siswa, tetapi sebagian guru juga menganggap geometri khususnya materi bangun ruang merupakan materi yang sulit sehingga mereka memerlukan pelatihan tambahan.Hal tersebut berdasarkan fakta dari hasil Training Need Assessment (TNA), Calon Peserta Diklat Guru Matematika SMP yang dilaksanakan PPPPTK Matematika tahun 2007 dengan sampel sebanyak 286 guru SMP dari 15 Provinsi menunjukkan bahwa materi luas permukaan dan volume balok, kubus,prisma, dan limas, 43,7\% guru menyatakan sangat memerlukan untuk pelatihan pembelajaran tersebut (Suwaji, 2008).

Berdasarkan hasil studi pendahuluan berupa wawancara dengan salah seorang guru matematika SMP, diperoleh informasi bahwa siswa mengalami kesulitan dalam menyelesaikan soal yang terkait dengan luas permukaan dan volume saat mereka dihadapkan pada soal yang berbeda dari contoh yang telah diberikan sebelumnya. Menurut hasil penelitian Lastianingsih, dkk (2004), hal tersebut terjadi dikarenakan siswa jarang mengerjakan latihan soal yang bervariasi. Mereka sering hanya di-drill untuk menghafal rumus dan mengerjakan soal-soal yang hampir identik, sehingga jika soal diubah sedikit saja mereka tidak mampu atau mengalami kesulitan dalam menyelesaikannya. Kesulitan seperti ini dikenal dengan hambatan epistimologis.

Menurut Duroux (Suryadi, 2010) hambatan epistimologis merupakan hambatan yang muncul akibat dari pengetahuan seseorang yang terbatas pada konteks tertentu. Jika orang tersebut berhadapan dengan konteks yang berbeda, maka pengetahuan yang dimiliki menjadi tidak dapat digunakan lagi atau dia akan mengalami kesulitan untuk menggunakannya. 
Jika siswa mengalami hambatan dalam proses belajarnya (learning obstacle) maka hambatan itu dapat menyebabkan siswa mengalami kegagalan atau setidaknya kurang berhasil dalam mencapai tujuan belajar. Di sinilah tugas seorang guru untuk meminimalisir hambatan-hambatan yang dapat muncul dalam proses pembelajaran. Salah satu faktor yang berpengaruh dalam meningkatkan pemahaman konsep siswa adalah kemampuan guru dalam mengembangkan bahan ajar. Sebelum proses pembelajaran dimulai, guru mempersiapkan bahan ajar yang digunakan serta strategi penyampaiannya agar bahan ajar tersebut dapat dengan mudah dipahami oleh siswa.

Desain Didaktis merupakan rancangan pembelajaran berupa bahan ajar yang dibuat berdasarkan penelitian learning obstacle pada pembelajaran matematika yang telah muncul sebelumnya. Desain didaktis dirancang dengan tujuan untuk mengatasi atau mengurangi learning obstacle yang muncul, agar siswa mampu memahami konsep suatu materi dalam matematika secara utuh. Dengan menggunakan desain didaktis diharapkan siswa tidak lagi menemui hambatan-hambatan dalam memahami suatu konsep matematika.

Berdasarkan uraian di atas, maka diperlukan penelitian mengenai desain didaktis konsep bangun ruang, khususnya yang terkait dengan luas permukaan dan volume prisma. Untuk itulah peneliti tertarik untuk meneliti Desain Didaktis Konsep Luas Permukaan dan Volume Prisma dalam Pembelajaran Matematika SMP”.

Adapun tujuan yang ingin dicapai dari penelitian ini yaitu (1) Mengidentifikasi learning obstacle yang terkait dengan konsep luas permukaan dan volume prisma. (2) Menyusun suatu desain didaktis konsep luas permukaan dan volume prisma. (3) Mengetahui respon siswa terhadap implementasi desain didaktis konsep luas permukaan dan volume prisma saat pembelajaran. (4) Mengetahui efektivitas dari desain didaktis luas permukaan dan volume prisma yang telah dibuat.

\section{METODE PENELITIAN}

Metode penelitian yang digunakan adalah metode kualitatif. Metode kualitatif ini dipilih agar dapat lebih rinci mengungkapkan gejala atau fenomena yang lebih kompleks dan sulit diungkapkan jika menggunakan metode kuantitatif. Seperti yang diungkapkan oleh Ruseffendi (2005) bahwa penelitian kualitatif itu perlu dilakukan untuk mengungkapkan sesuatu yang oleh penelitian kuantitatif belum terungkapkan. 
Subjek pada penelitian ini terbagi menjadi dua, yaitu subjek pada uji instrumen learning obstacle dan subjek pada implementasi desain didaktis. Subjek untuk mengidentifikasi learning obstacle yaitu siswa kelas IX SMP Negeri 6 Cirebon sebanyak 35 siswa, siswa kelas IX SMP Negeri 44 Bandung sebanyak 68 siswa, dan siswa kelas X SMA Negeri 3 Cirebon sebanyak 39 siswa. Sedangkan, subjek pada implementasi desain didaktis adalah siswa kelas VIII di SMP Negeri 44 Bandung dengan total sebanyak 43 siswa.

Adapun tahapan yang akan dilakukan pada penelitian ini secara lebih rinci akan diuraikan sebagai berikut:

Tahap I: Analisis situasi didaktis sebelum pembelajaran

1. Menentukan materi matematika yang akan dijadikan bahan penelitian.

2. Menganalisis materi matematika yang telah dipilih.

3. Melakukan telaah susunan materi matematika yang telah dipilih tersebut pada buku-buku sumber yang ada.

4. Mengembangkan instrumen learning obstacle dengan menyusun indikator kemampuan mengerjakan soal pada tiap nomornya, dan membuat/memilih soalsoal yang variatif serta dapat memunculkan kesulitan siswa mengenai konsep luas permukaan dan volume prisma.

5. Melakukan uji instrumen learning obstacle dilanjutkan dengan tanya jawab untuk mengidentifikasi learning obstacle.

6. Menganalisis hasil uji instrumen learning obstacle dengan menghitung persentase banyaknya siswa yang mencapai suatu indikator.

7. Mengelompokkan jenis kesulitan siswa.

8. Membuat lintasan belajar untuk mempelajari materi luas permukaan dan volume prisma.

9. Mengembangkan desain diaktis berdasarkan learning obtacle yang muncul dan menyesuaikan dengan teori belajar yang relevan, selain itu pengembangan desain didaktis juga perlu memperhatikan kemampuan-kemampuan matematika yang dapat dikembangkan.

10. Membuat prediksi respon siswa terhadap desain didaktis yang akan diimplementasikan dan mempersiapkan antisipasi didaktisnya 
Tahap II: Analisis metapedadidaktik

1. Melakukan implementasi desain didaktis yang telah dibuat.

2. Menganalisis hasil implementasi desain didaktis berbagai respon siswa saat implementasi desain didaktis.

Tahap III: Analisis retrosfektif

1. Mengaitkan antara prediksi awal yang telah dibuat sebelum implementasi dengan respon siswa saat implementasi berlangsung sebagai rujukan untuk revisi desain didaktis.

2. Mengukur efektivitas desain didaktis dengan melakukan pengujian instrumen learning obstaclekepada siswa yang telah menerima pembelajaran menggunakan desain didaktis kemudian menganalisis hasil pengujian instrumen learning obstacletersebut untuk melihat apakah kesulitan siswa yang telah teridentifikasi sebelumnya masih muncul atau tidak.

Teknik pengumpulan data dalam penelitian ini dilakukan dengan melakukan uji instrumen learning obstacle, implementasi desain didaktis, observasi, tanya jawab dan dokumentasi. Sedangkan analisis data pada penelitian ini dilakukan dengan terlebih dahulu mengumpulkan seluruh data yang diperoleh untuk selanjutnya dilakukan penyeleksian dan pengelompokkan data yang ada kemudian melakukan interpretasi secara naratif.

Efektivitas dari desain didaktis akan diuji dengan cara membandingkan persentase hasil tes siswa yang belajar menggunakan bahan ajar sekolah dengan siswa yang belajar menggunakan desain didaktis. Besarnya derajat peningkatan siswa yang menjadi subjek pengujian istrumen learning obstacle dengan siswa yang belajar menggunakan desain didaktis dihitung dengan gain ternormalisasi yang diadaptasi dari Hake (1999), dengan rumusan sebagai berikut:

$$
<e>=\frac{\% \text { Akhir }-\% \text { Awal }}{100-\% \text { Awal }}
$$

<e>adalah derajat peningkatan, dengan kategori sebagai berikut:

Tabel 1. Kriteria Derajat Peningkatan $\langle\mathrm{e}>$

\begin{tabular}{cc}
\hline Besarnya e & Interpretasi \\
\hline $\mathrm{e} \geq 0,7$ & Tinggi \\
$0,3 \leq \mathrm{e}<0,7$ & Sedang \\
$0<\mathrm{e}<0,3$ & Rendah \\
$\mathrm{e} \leq 0$ & Tidak Efektif \\
\hline
\end{tabular}




\section{HASIL DAN PEMBAHASAN}

Hasil analisis kemampuan siswa dalam mengerjakan soalterkaitkonsep luas permukaan dan volume prisma menunjukkan beberapa kesulitan yang dialami siswa saat menyelesaikan instrumen learning obstacle. Berdasarkan hasil analisis tersebut, terdapat empat jenis kesulitan belajar (learning obstacle) yang dialami siswa dalam memahami konsep luas permukaan dan volume prisma, yaitu: siswa kesulitan dalam menentukan alas dari suatu prisma, siswa kesulitan dalam merumuskan luas permukaan prisma, siswa kesulitan dalam merumuskan volume prisma, dan siswa kesulitan dalam membuat keterkaitan dengan konsep matematika lainnya.

Tahapan pengembangan desain didaktis konsep luas permukaan dan volume prisma yaitu: membuat lintasan belajar dalam memahami konsep luas permukaan dan volume prisma, mengembangkan desain didaktis berdasarkan learning obstacleyang telah teridentifikasi dengan menyesuaikan pada teori-teori belajar yang relevan,serta mengembangkan beberapa kemampuan matematika seperti kemampuan pemahaman, penalaran, pemecahan masalah, koneksi, dan komunikasi.

Sebelum desain didaktis diimplementasikan, perlu dibuat prediksi berbagai macam respon siswa beserta antisipasi didaktisnya. Desain didaktis yang telah disusun selanjutnya diimplementasikan dalam proses pembelajaran kepada siswa kelas VIII SMP.

Desain didaktis diimplementasikan pada dua pertemuan, pertemuan pertama mengimplementasikan desain didaktis konsep luas permukaan prisma dan pertemuan kedua mengimplementasikan desain didaktis konsep volume prisma. proses implementasi desain didaktis pada tiap pertemuan terdiri dari tiga bagian yaitu: apersepsi, kegiatan inti, dan kegiatan akhir.

Saat implementasi desain didaktis berlangsung, respon yang sesuai dengan prediksi dapat ditindaklanjuti dengan memberikan antisipasi didaktis yang telah direncanakan sebelumnya. Sedangkan respon siswa di luar prediksi yang mucul juga perlu ditindaklanjuti dengan memberikan respon didaktis disesuaikan dengan kondisi yang ada.

Hasil implementasi desain didaktis menunjukkan bahwa pada bagian desain didaktis pengembangan pemahaman konsep luas permukaan dan volume prisma, siswa memperoleh pengalaman belajar yang bermakna sehingga siswa mampu memahami konsep luas permukaan dan volume prisma dengan baik. Pada bagian ini, siswa terlebih 
dahulu mengerjakan secara individu. Selanjutnya, di akhir bagian ini dilakukan diskusi kelas untuk meluruskan pemahaman siswa yang masih keliru dan memberikan penguatan pada pemahaman yang telah dimiliki siswa. Sedangkan pada pengembangan pemahaman konsep luas permukaan dan volume prisma terkait dengan konteks aplikasi pada soal-soal latihan, siswa terlihat kesulitan dalam menyelesaikan soal. Siswa membutuhkan bimbingan dalam menyelesaikan soal tersebut dengan diberikan petunjuk-petunjuk sederhana.

Setelah proses implementasi desain didaktis selesai, selanjutnya siswa diberikan tes dengan menggunakan soal yang sama saat mengidentifikasi learning obstacle. Hasil persentase tes tersebut akan dibandingkan dengan hasil persentase saat uji instrumen learning obstacleuntuk menghitung besarnya derajat peningkatan pada tiap butir soal. Derajat peningkatan tersebut selanjutnya digunakan untuk menentukan tingkat keefektivitasan dari desain didaktis yang telah dibuat.

Berikut ini adalah hasil persentase pengerjaansiswa yang telah mendapatkan pembelajaran menggunakan desain didaktis dalam menyelesaikan soal konsep perbandingan segmen garis dibandingkan dengan siswa yang mendapatkan pembelajaran menggunakan bahan ajar sekolah (dalam hal ini adalah siswa yang telah mengikuti uji instrumen learning obstacle).

Tabel 2. Efektivitas Desain Didaktis

\begin{tabular}{|c|c|c|c|c|}
\hline $\begin{array}{l}\text { No. } \\
\text { Soal }\end{array}$ & Jenis Kemampuan & $\begin{array}{l}\text { Bahan Ajar } \\
\text { Sekolah } \\
(\%)\end{array}$ & $\begin{array}{l}\text { Desain } \\
\text { Didaktis } \\
(\%)\end{array}$ & $\begin{array}{c}\text { Rata-Rata } \\
\text { Derajat } \\
\text { Peningkatan } \\
<\mathrm{e}>\end{array}$ \\
\hline \multirow[t]{2}{*}{1} & $\begin{array}{l}\text { Mencari panjang alas prisma } \\
\text { menggunakan konsep Pythagoras. }\end{array}$ & 91,18 & 93,02 & 0,39 \\
\hline & Menghitung luas permukaan prisma & 45,59 & 76,74 & \\
\hline \multirow[t]{4}{*}{2} & Mengkonstruksi alas prisma & 22,06 & 30,23 & 0,45 \\
\hline & $\begin{array}{l}\text { Mencari diagonal } 2 \text { dengan konsep } \\
\text { Pythagoras }\end{array}$ & 33,83 & 74,42 & \\
\hline & $\begin{array}{lll}\text { Menghitung luas alas prisma } \\
\text { menggunakan } & \text { konsep luas belah } \\
\text { ketupat } & & \end{array}$ & 32,35 & 69,77 & \\
\hline & Menghitung volume prisma & 32,35 & 69,77 & \\
\hline \multirow[t]{4}{*}{3} & $\begin{array}{l}\text { Menentukan alas prisma berdasarkan } \\
\text { sifat-sifat prisma. }\end{array}$ & 23,53 & 86,05 & 0,68 \\
\hline & $\begin{array}{l}\text { Menghitung luas alas prisma (luas } \\
\text { trapesium) }\end{array}$ & 22,06 & 72,09 & \\
\hline & Menghitung volume prisma & 19,19 & 72,09 & \\
\hline & $\begin{array}{l}\text { Mengubah satuan volume dari } \mathrm{m}^{3} \mathrm{ke} \\
\text { Liter }\end{array}$ & 14,71 & 67,44 & \\
\hline
\end{tabular}


$4 \quad$ Menghitung luas alas prisma

Mencari panjang sisi-sisi alas prisma

dengan konsep perbandingan dan

aljabar

Menghitung luas permukaan prisma
$79,41 \quad 88,37$

$26,47 \quad 58,14$

53,49

Catatan: 68 siswa bahan ajar sekolah, 43 siswa desain didaktis.

Dengan menjumlahkan seluruh derajat peningkatan pada setiap indikator kemampuan mengerjakan soal kemudian membaginya dengan banyaknya indikator yang ada, diperoleh rata-rata derajat peningkatan dari desain didaktis konsep luas permukaan dan volume prisma adalah sebesar 0,51. Dengan demikian desain didaktis konsep luas permukaan dan volume prisma yang telah disusun ini dapat dikategorikan efektif sedang. Berdasarkan hasil implementasi dan efektivitas desain didaktis yang telah diukur, dapat dikatakan bahwa desain didaktis yang telah disusun ini cukup efektif untuk diterapkan dalam pembelajaran konsep luas permukaan dan volume prisma.

\section{KESIMPULAN}

Berdasarkan analisis dari hasil penelitian dan pembahasan, dapat ditarik kesimpulan sebagai berikut:

1. Terdapat empat jenis kesulitan belajar (learning obstacle) yang dialami siswa dalam memahami konsep luas permukaan dan volume prisma, yaitu: siswa kesulitan dalam menentukan alas dari suatu prisma, siswa kesulitan dalam merumuskan luas permukaan prisma, siswa kesulitan dalam merumuskan volume prisma, dan siswa kesulitan dalam membuat keterkaitan dengan konsep matematika lainnya.

2. Desain didaktis dikembangkan untuk mengatasi kesulitan-kesulitan belajar yang dialami siswa dalam memahami konsep luas permukaan dan volume prisma. Pengembangan desain didaktis ini juga disesuaikan dengan teori-teori belajar yang relevan. Disamping itu, desain didaktis ini juga dibuat dengan tidak mengurangi kemampuan-kemampuan matematika, seperti kemampuan pemahaman, penalaran, pemecahan masalah, koneksi, dan komunikasi.

3. Respon siswa terhadap implementasi desain didaktis konsep luas permukaan dan volume prisma sebagian besar sesuai dengan prediksi yang telah dibuat sebelumnya. Tetapi ada pula respon siswa yang tidak sesuai dengan prediksi, yaitu siswa melupakan beberapa konsep matematika lain yang telah dipelajari 
sebelumnya seperti konsep Pythagoras, rumus luas layang-layang dan trapesium, serta konsep perbandingan. Untuk mengatasinya, siswa perlu diingatkan kembali tentang konsep lain yang terkait tersebut agar siswa mampu menyelesaikan latihan soal yang diberikan. Selain itu, terdapat hambatan dikarenakan keterbatasan waktu sehingga siswa tidak dapat menyelesaikan latihan soal seluruhnya sehingga soal yang belum siswa selesaikan dijadikan sebagai tugas mandiri bagi siswa.

4. Efektivitas desain didaktis diukur menggunakan derajat peningkatan persentase banyaknya siswa yang mampu mengatasi kesulitan belajar dalam memahami konsep luas permukaan dan volume prisma. Desain didaktis yang dikembangkan menunjukkan kategori efektif sedang.

Berdasarkan kesimpulan dari hasil penelitian dan pembahasan pada penelitian ini, adapun saran yang dapat diajukan adalah sebagai berikut: (1)Desain didaktis yang telah disusun ini dapat dijadikan salah satu alternatif bahan ajar yang dapat digunakan dalam proses pembelajaran konsep luas permukaan dan volume prisma. (2) Sebelum mengimplementasikan desain didaktis ini, guru perlu mengkaji lebih dalam tentang materi terkait. Selain itu, perlu dibuat lebih banyak prediksi respon siswa yang akan muncul beserta antisipasi didaktisnya. (3) Guru perlu memastikan materi prasyarat telah dikuasai oleh siswa agar desain didaktis dapat diimplementasikan secara efektif. Penelitian ini diharapkan dapat terus dikembangkan agar diperoleh sebuah desain didaktis konsep luas permukaan dan volume prisma yang lebih baik lagi.

\section{DAFTAR PUSTAKA}

Ed, Kohn. (2003). Seri matematika keterampilan geometri. Bandung: Pakar Raya.

Hake, R.R. (1999). Analyzing change / gain scores.Juni 08, 2012.http://www.physics.indiana.edu/ sdi/AnalyzingChange-Gain.pdf

Lastiningsih, Netti., Siswono, Tatag YE., dan Manoy, Janet T. (2004). Penerapan pendekatan pembelajaran konstektual untuk mengatasi kesulitan siswa dalam belajar matematika bangun ruang sisi tegak di kelas I sltp negeri 6 sidoarjo.Maret 18, 2012.http://tatagyes.files.wordpress.com/2009/11/paper04_ctl3.pdf

Ruseffendi. (2005).Dasar-dasar penelitian pendidikan dan bidang non-eksata lainnya. Bandung : Tarsito.

Suryadi, Didi. (2010). Didactical design research (DDR) dalam pengembangan pembelajaran matematika. Modul Semnas MIPA 2010.

Suwaji, U.T. (2008). Permasalahan pembelajaran geometri ruang smp dan alternatif pemecahannya. Yogyakarta: Departemen Pendidikan Nasional. 